\title{
PEMBERDAYAAN SERTA EDUKASI KREATIF MEWUJUDKAN MASYARAKAT SEHAT DAN TANGGAP COVID-19
}

\author{
Vella Rohmayani ${ }^{1}$, Idham Choliq ${ }^{2}$, Islam Syarifurrahman ${ }^{3}$, Lihabi ${ }^{4}$ \\ ${ }^{1}$ Program Studi DIV Teknologi Laboratorium Medis Fakultas Ilmu Kesehatan UM Surabaya \\ 2 Program Studi S1 Keperawatan Fakultas Ilmu Kesehatan UM Surabaya \\ ${ }^{3}$ Progarm Studi S2 Keperawatan FKP Universitas Airlangga Surabaya \\ ${ }^{4}$ Prodi D4 TLM Poltekkes Surabaya \\ E-mail : vella.yani@fik.um-surabaya.ac.id¹,idhamcholiq@fik.um-surabaya.ac.id, \\ islamsyarifurrahman@gmail.com, lihabiabi@gmail.com
}

\section{Submitted : 27 Agustus 2021 Accepted: 29 Agustus 2021 Published: 31 Agustus 2021}

\begin{abstract}
Abstrak: Pandemi Covid-19 yang tak kunjung usai membuat sebagian masyarakat mulai lelah dan abai menerapkan protokol kesehatan, termasuk masyarakat pesisir Sukolilo, Surabaya. Di lokasi tersebut sudah banyak dijumpai masyarakat yang sudah beraktivitas seperti kehidupan normal layaknya sebelum pandemic Covid-19 terjadi. Banyak masyarakat yang sudah beraktivitas di luar rumah tanpa memakai masker, menjaga jarak, dan lain seterusnya. Padahal pandemic Covid-19 gelombang kedua menyebabkan kasus kesakitan maupun angka kematian yang jauh lebih tinggi dibandingkan pandemic sebelumnya. Oleh sebab itu menjadi penting untuk dilakukan edukasi kreatif guna menyadarkan masyarakat akan pentingnya menerapakan protokol kesehatan agar dapat terhindar dari penularan penyakit Covid-19. Kegiatan edukasi kreatif dilakukan melalui poster dan video beragam bahasa, yaitu bahasa Indonesia, Jawa dan Madura sehingga masyarakat lebih mudah memahami terkait gejala, penularan dan pencegahan Covid-19. Kegiatan edukasi tersebut dilakukan dengan menggunakan metode door to door, sehingga tidak ada kegiatan pengumpulan masa yang dapat meningkatkan resiko penularan Covid-19. - Masyarakat tersebut sangat antusias dengan kegiatan edukasi yang dilakukan, mereka juga menjadi lebih disiplin dalam menerapakan protokol kesehatan guna menghindari penularan penyakit Covid-19.
\end{abstract}

Kata kunci: Edukasi Kreatif, Covid-19, dan peningkatan pengetahuan masyarakat. 


\section{PENDAHULUAN}

Pandemi Covid-19 yang tak kunjung usai membuat sebagian masyarakat mulai lelah dan abai menerapkan protokol kesehatan, termasuk pada masyarakat pesisir desa Sukolilo, Surabaya. Di lokasi tersebut sudah banyak dijumpai masyarakat yang sudah beraktivitas seperti kehidupan normal layaknya sebelum pandemic Covid-19 terjadi. Banyak masyarakat yang sudah beraktivitas di luar rumah tanpa memakai masker, menjaga jarak, dan lain seterusnya.

Padahal pandemic Covid-19 gelombang kedua menyebabkan kasus kesakitan maupun angka kematian yang jauh lebih tinggi dibandingkan pandemic sebelumnya. Pemerintah mencatat angka kesakitan covid-19 sejak pertama kali diumumkan hingga tertanggal 17 Agustus 2021 adalah sebesar 3.892.479 kasus, sedangkan angka kematian sebesar 120.013 kasus (Kompas. com, 2021).

Di tengah kondisi pandemic Covid-19, sudah seharusnya perguruan tinggi bergerak dan ikut melakukan aksi guna meningkatkan pemahaman masyarakat. Kegiatan pengabdian kepada masyarakat yang merupakan salah satu tri darma perguruan tinggi menjadi bagian yang tidak bisa terpisahkan saat pandemi Covid-19 terjadi.

Oleh sebab itu mahasiswa dan dosen dari Fakultas Ilmu Kesehatan Universitas Muhammadiyah Surabaya tergerak untuk melakukan aksi edukasi kreatif guna untuk menyadarkan masyarakat akan pentingnya menerapakan pola hidup sehat dan protokol kesehatan agar dapat terhindar dari penularan penyakit Covid-19.

\section{TINJAUAN PUSTAKA}

\subsection{Penyakit Covid-19}

Penyakit Covid-19 merupakan penyakit jenis baru yang disebabkan oleh adanya infeksi virus Sars-Cov-2, dan telah dinyatakan sebagai pandemic oleh Organisasi Kesehatan Dunia (WHO) pada 11 Maret 2020 (Qun Li et al., 2020). Virus SARS-CoV-2 ini pertama kali diidentifikasi pada pasien di Wuhan, Hubei China, pada bulan Desember 2019 yang kemudian diindikasi dan dinamai sebagai $\beta$-coronavirus (nCoV) (Tian X. et al., 2020).

Masa inkubai yang dibutuhkan pada kasus Covid-19 rata-rata berkisar antara 5-7 hari dengan masa inkubasi terlama 14 hari. Penyakit ini dapat menimbulkan gejala ringan hingga gejala berat. Tanda dan gejala klinis yang dirasakan oleh sebagian besar orang yang terpapar virus Sars-CoV-2 adalah deman dan batuk, dan beberapa orang ada yang mengalami gejala berat, yaitu sesak napas sindrom pernapasan akut dimana dari hasil rontgen menunjukkan infiltrat pneumonia luas di kedua paru, gagal ginjal, dan bahkan kematian (KEMENKES, 2020).

Saat ini, penyebaran SARS-CoV-2 dari manusia ke manusia menjadi sumber transmisi utama sehingga penyebaran menjadi lebih agresif. Transmisi SARS-CoV-2 dari pasien simptomatik terjadi melalui droplet yang keluar saat batuk atau bersin. Sehingga pencegahan yang dapat dilakukan untuk mengurangi angka penularan Covid-19 adalah dengan cara melakukan 5M, yaitu memakai masker, menjaga jarak, mencuci tangan, membatasi mobilitas dan menjauhi kerumunan.

\subsection{Edukasi Kesehatan}

Pendidikan Kesehatan adalah usaha sadar atau menimbulkan perubahan tingkah laku hidup sehat, baik lingkungan masyarakat dan sosial. Pendidikan kesehatan adalah proses perubahan perilaku yang dinamis dimana perubahan tersebut bukan sekedar proses transfer materi atau teori dari seseorang ke orang lain, tetapi dilakukan untuk mengubah perilaku masyarakat dengan menggugah kesadaran dari dalam diri individu kelompok 
atau masyarakat itu sendiri (Mubarok dan Chayatin, 2009).

Pendidikan kesehatan memiliki tujuan sebagai berikut (Lutan dkk., 2001):

1. Meningkatkan perilaku sehat yang meliputi pilihan, tindakan, kebiasaan yang positif bagi perkembangan gaya hidup yang sehat.

2. Membantu perkembangan kepribadian yang seimbang.

3. Memperjelas kesalahan konsep dan menyediakan informasi yang akurat tentang fakta kesehatan pribadi dan masyarakat.

4. Menyumbang pada pembentukan kesehatan masyarakat melalui pengembangan warga Negara yang terdidik - sehat sehingga mendukung takaran sehat dimasa mendatang.

5. Mengembangkan kemauan anak untuk melihat sebab akibat tentang kesehatan, mengambil langkah pencegahan, dan penyembuhan di mana memungkinkan, memperbaiki dan meningkatkan kualitas hidup.

\section{METODE PENGABDIAN KEPADA}

\section{MASYARAKAT}

\subsection{Tempat dan waktu pelaksanaan}

Kegiatan pengabdian berupa edukasi kreatif terkait penyakit Covid-19 ini dilakukan bekerjasama dengan ketua RT dan RW yang berada di area perkampungan pesisir Sukolilo, Surabaya. Kegiatan edukasi ini dilaksanakan pada bulan Juni 2021.

\subsection{Masyarakat sasaran}

Masyarakat sasaran kegiatan edukasi kreatif ini adalah masyarakat pesisir Sukolilo, Surabaya yang notabene bekerja sebagai nelayan dan pedagang yang menjual berbagai olahan hasil laut. Masyarakat di lokasi tersebut masyoritas merupakan masyarakat yang fasih berbahasa madura maupun jawa, oleh sebab itu kegiatan edukasi ini dilakukan menggunakan bahaya daerah, yaitu bahasa madura dan bahasa Jawa. Hal tersebut dilakukan agar masyarakat lebih mudah memahami terkait penyebab, gejala, cara penularan dan cara pencegahan terhadap penyakit Covid-19.

\subsection{Prosedur pelaksanaan}

Adapun Prosedur pelaksanaan kegiatan edukasi dilakukan dalam tiga tahapan, yaitu:

1. Tahap persiapan, meliputi kegaiatan observasi lapangan, perizinan, penentuan tanggal pelaksanaan, persiapan alat dan bahan edukasi.

2. Tahap pelaksanaan, meliputi kegiatan edukasi kreatif melalui poster dan video beragam bahasa, yaitu bahasa Indonesia, Jawa dan Madura sehingga masyarakat lebih mudah memahami terkait gejala, penularan dan pencegahan Covid-19. Kegiatan edukasi tersebut dilakukan dengan menggunakan metode door to door, sehingga tidak ada kegiatan pengumpulan masa yang dapat meningkatkan resiko penularan Covid-19.

3. Tahap evaluasi dilakukan untuk menilai atau mengevaluasi kegiatan pengabdian masyarakat berupa edukasi kreatif melalui wawancara dengan masyarakat terkait dengan pengetahuan, sikap dan tindakan terhadap pencegahan dan penanggulangan penyakit Covid-19.

\section{HASIL DAN PEMBAHASAN}

Penyakit Covid-19 yang merupakan penyakit yang menyerang system pernafasan membuat penyakit ini dapat dengan mudah menyerang dari satu orang ke orang lainnya. Oleh sebab itu seluruh elemen masyarakat tanpa terkecuali harus berperan aktif dalam mencegah dan menanggulangi penyebaran penyakit Covid-19.

Kegiatan pengabdian masyarakat berupa edukasi kreatif dilaksanan menggunakan metode door to door atau dari satu rumah ke 
rumah lainnya. Hal tersebut dilakukan untuk menghindari pengumpulan masa yang dalam meningkatkan resiko penularan penyakit Covid-19.

Kegiatan edukasi kreatif dilakukan melalui poster edukasi dan sosialisasi lewat video dengan beragam bahasa daerah, yaitu bahasa madura dan bahasa jawa. Karena masyrakat pesisir Sukolilo, Surabaya merupakan masyarakat yang fasih menggunakan kedua bahasa tersebut.

Edukasi protokol Kesehatan berbahasa daerah ini dilakukan dengan tujuan, agar masyarakat dapat lebih mudah dalam

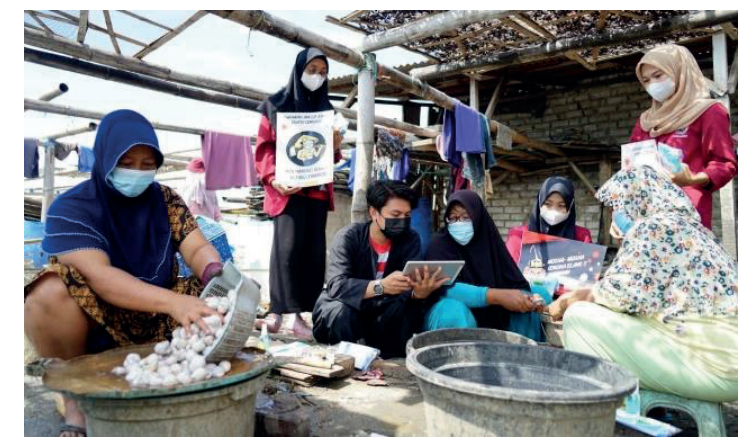

a memamahi penyakit Covid-19 baik terkait penyebab, gejala yang ditimbulkan, proses penularan penyakit, serta langkah-langkah pencegahan penyakit Covid-19. Dengan memahami penyakit Covid-19 secara baik, maka kesadaran dan tingkat kedisiplinan masayarakat untuk menerapakan budaya hidup bersih dan sehat, serta menerapkan protokol kesehatan akan meningkat. Oleh sebab itu kegiatan edukasi kesehatan ini penting untuk dilakukan, guna mengubah perilaku masyarakat dengan menggugah kesadaran dari dalam diri individu kelompok atau masyarakat itu sendiri (Mubarok dan Chayatin, 2009).

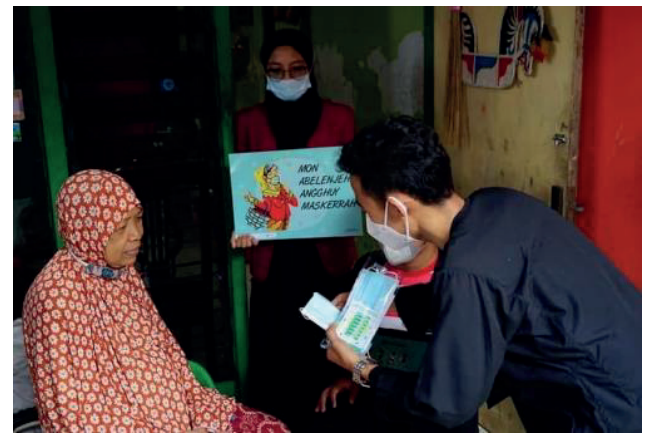

b

Gambar 1. Edukasi Covid-19 melalui Video dan Poster; a. edukasi kepada masyarakat pesisir Sukolilo yang sedang mengolah hasil laut, b. edukasi kepada masyarakat dari rumah ke rumah

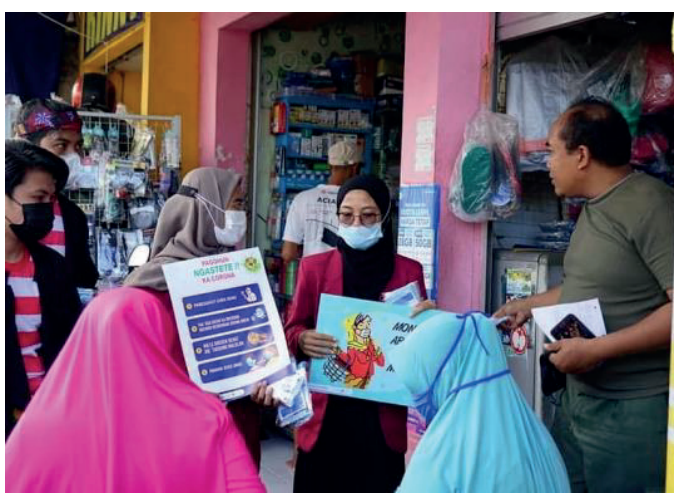

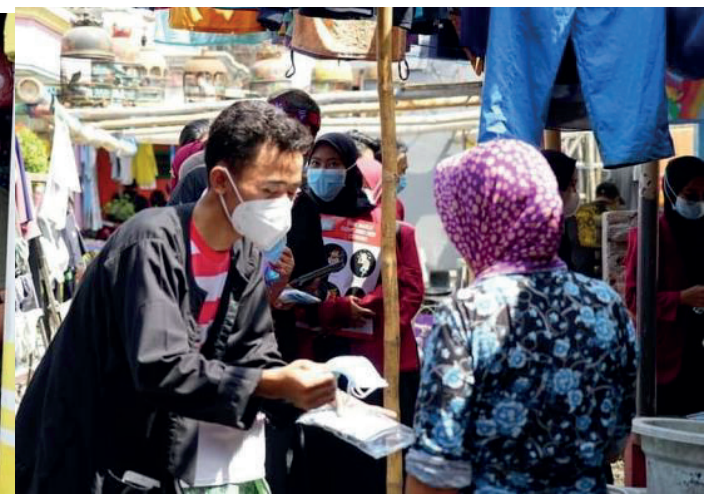

Gambar 2. a. Edukasi Covid-19 melalui poster kepada masyarakat di pesisir sukolilo; b. pembagian masker dan hand sanitizer pada masyarakat. 
Dari gambar 1 dan 2 dapat dilihat mahasiswa sedang melakukan edukasi Covid-19 serta membagikan masker dan hand sanitizer kepada masyarakat yang sedang berjualan, mengolah hasil laut, maupun masyarakat yang sedang beraktivitas di rumah masing-masing. Dalam gambar tersebut dapat di terlihat ada beberapa masyarakat yang sudah tidak disiplin menerapkan protokol kesehatan.

Kegiatan ini dilakukan guna untuk mengigatkan kembali serta memotivasi masyarakat agar lebih taat protokol kesehatan saat beraktivitas di luar rumah. Saat melakukan edukasi kepada masyarakat dosen dan mahasiswa Fakultas Ilmu Kesehatan (FIK) tetap menjaga protokol kesehatan secara ketat, seperti memakai masker, mencuci tangan dan menjaga jarak. Dengan dilakukannya kegiatan edukasi kreatif ini, diharapkan akan terwujud masyarakat sehat yang tanggap Covid-19. Karena kesehatan merupakan hal penting yang harus senantiasa kita jaga bersama.

\section{KESIMPULAN}

Kegiatan pengabdian kepada masyarakat yang beruapa edukasi kreatif terkait Covid-19 di wilayah perkampungan pesisir sukolilo Surabaya telah dilaksanaan dengan baik. Kegiatan edukasi dilakukan disertai dengan kegiatan bagi-bagi masker dan hand sanitizer kepada masyarakat. Melalui kegiatan ini terjalin Kerjasama antara institusi perguruan tinggi dengan pemerintah daerah yaitu RT dan RW setempat dalam uapaya mencengah dan menanggulangi penularan penyakit Covid-19. Kegiatan edukasi ini diharapkan dapat berkelanjutan sehingga masyarakat tersebut menjadi lebih disiplin dalam menerapakan protokol kesehatan guna menghindari penularana penyakit Covid-19.

\section{Ucapan Terima Kasih}

Disampaikan terima kasih kepada berbagai pihak yang membantu kelancaran kegiatan pengabdian ini, yaitu kepada:

a. Ketua RT maupun RW wilayah pesisir Sukolilo Surabaya yang bersedia memberikan perizinan untuk pelaksanaan kegiatan pengabdian berupa edukasi kreatif terkait Covid-19

b. Masyarakat wilayah pesisir Sukolilo Surabaya yang sangat antusias terhadap pelaksanaan kegiatan pengabdian berupa edukasi kreatif terkait Covid-19

c. Kader Ikatan Mahasiswa Muhammadiyah Fakultas Ilmu Kesehatan UM Surabaya yang membantu pelaksanaan kegiatan edukasi kreatif.

\section{DAFTAR PUSTAKA}

Kompas.com (17 Agustus 2021). UPDATE: Tambah 32.225, Total Pasien Covid-19 yang Sembuh 3.414.109 Orang. Diakses pada 19 Agustus 2021, dari: https://nasional.kompas.com/ $\mathrm{read} / 2021 / 08 / 17 / 16383281 /$ update-tambah-32225-total-pasien-covid-19-yangsembuh-3414109-orang

Li Q, Guan X, Wu P, Wang X, Zhou L, Tong $\mathrm{Y}$, et al. Early transmission dynamicsin Wuhan, China, of novel coronaviruseinfected pneumonia. N Engl J Med 382:199-207.

Lutan Rusli. Hartoto.Tomoliyus. 2001. Pendidikan Kebugaran Jasmani Orientasi Pembinaan Disepanjang Hayat. Dirjen Olahraga. Depdiknas.

Mubarak, Wahid Iqbal dan Chayatin, Nurul. 2009. Ilmu Kesehatan Masyarakat Teori dan Aplikasi. Jakarta: Salemba Medika.

Tian X, Li C, Huang A, Xia S, Lu S, Shi Z, et al. 2020. Potent binding of 2019 novel corona virus spike protein by a SARS coronavirus-specific human monoclonal antibody. Emerg Microb Infect 9(1):382385. 